\title{
BISNIS KULINER
}

\section{BANANA ROLL (BANROL)}

Makalah Ini Disusun untuk Memenuhi Tugas Akhir pada Mata Kuliah Kewirausahaan



Disusun Oleh:

Kelompok 1

- Indi

90500120119

- Ulfa Ramdhani

90500120099

- Widiyanti

90500120105

- Muhammad Emir khaerat 90500120117

- Lisna

90500120090

Dosen Pengampu : Dra. Hj. Nuraeni Gani, MM

\author{
PERBANKAN SYARIAH
}

FAKULTAS EKONOMI DAN BISNIS ISLAM

UNIVERSITAS ISLAM NEGERI ALAUDDIN MAKASSAR

TAHUN 2021 


\section{KATA PENGANTAR}

Puji dan syukur kami panjatkan kepada Tuhan Yang Maha Esa karena berkat rahmat dan karunia-nya lah. Sehingga "Makalah Bisnis Kuliner Banana Roll” ini dapat kami selesaikan dengan cukup mudah dan sesuai dengan waktu yang telah ditentukan tanpa pertolongan mungkin kami tidak bisa menyelesaikan laporan ini dengan tepat waktu.

Kami mengucapkan terima kasih kepada ibu Dra. Hj. Nuraeni Gani, MM. selaku Dosen Kewirausahaan yang telah memberikan tugas laporan ini yang nantinya dapat memberikan wawasan yang lebih luas kepada para pembaca kami menyadari bahwa laporan ini sangat banyak kekurangannya. Oleh karena itu kami mengharapkan kritik dan saran yang dapat membangun laporan ini.

Terima kasih.

Gowa, 16 Desember 2021

Penulis 


\section{DAFTAR ISI}

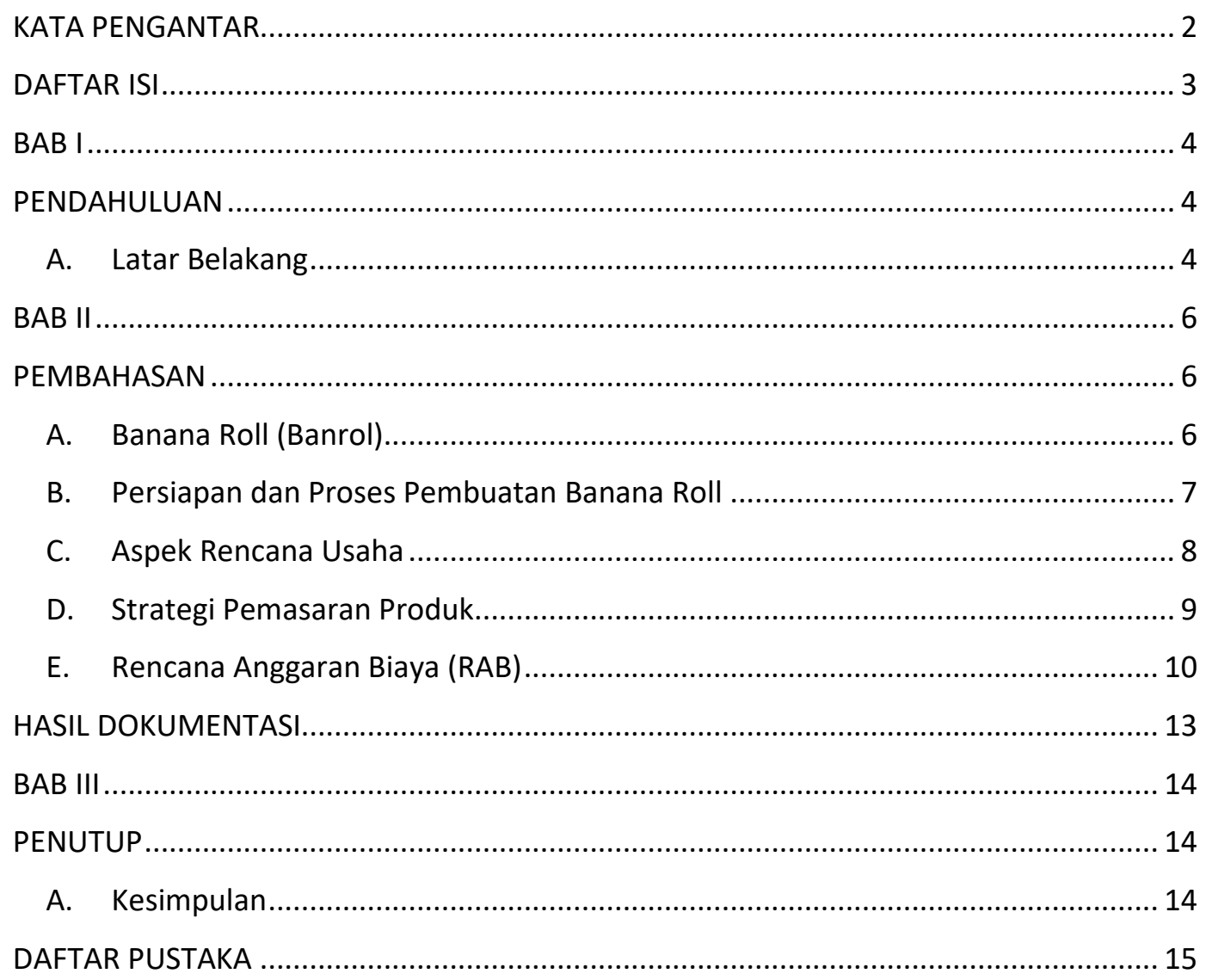




\section{BAB I}

\section{PENDAHULUAN}

\section{A. Latar Belakang}

Kewirausahaan merupakan kemampuan kreatif dan inovatif yang menjadi dasar untuk mencari peluang menuju sukses. Suatu hal yang baru dan berbeda merupakan nilai tambah barang dan jasa yang menjadi sumber keuanggulan untuk dijadikan peluang. Kewirausahaan adalah sebuah kemampuan untuk menciptakan nilai tambah di pasar melalui proses pengelolaan sumber daya dengan cara-cara baru dan berbeda.

Orang yang melakukan kegiatan kewirausahaan disebut wirausahawan. Mereka mempunyai motivasi, panggilan jiwa, persepsi dan emosi yang sangat terkait dengan nilai nilai, sikap dan perilaku sebagai manusia unggul. Pada makalah ini dijelaskan tentang pengertian, hakekat, ciri-ciri dan karakteristik dan peran kewirausahaan dalam perekonomian nasional.

Dalam makalah ini kami membahas tentang produk Banana Roll. Usaha ini awali dengan skala industri kecil rumahan. Produk ini merupakan salah satu produk yang dapat meningkatkan nilai ekonomi dari buah pisang dan menjadi jajanan yang cocok untuk dikonsumsi segala kalangan.

\section{B. Rumusan Masalah}

1. Apa yang dimaksud bisnis banana roll (banroll)?

2. Bagaimana persiapan dan proses pembuatan Banana Roll (banrol)?

3. Bagaimana aspek rencana usaha?

4. Bagaimana strategi pemasaran pada usaha bisnis Banana Roll (banrol)? 
5. Bagaimana Rencana Anggaran Biaya (RAB) pada bisnis Banana Roll (banrol)?

\section{Tujuan Usaha}

usaha ini dibuat untuk meningkatkan ekonomi bagi pendiri usaha, meningkatkan kreativitas dalam mengelola bahan makanan, dapat memiliki pekerjaan/usaha sendiri, serta memenuhi keinginan orang-orang yang suka makanan cepat saji.

\section{Manfaat}

1. Sebagai media untuk memperoleh penghasilan sampingan

2. Meningkatkan kreativitas dalam mengelola makanan

3. Sebagai media pemenuhan keinginan orang-orang yang suka makanan cepat

4. Menciptakan lapangan kerja sendiri 


\section{BAB II}

\section{PEMBAHASAN}

\section{A. Banana Roll (Banrol)}

Banana roll merupakan pisang yang dibalut dengan kulit lumpia dengan toppig coklat leleh diatasnya. Produk ini sebelumnya sudah terkenal dikalangan masyarakat. Usaha ini akan dimulai dari usaha dengan skala industri kecil rumahan. Produk ini merupakan salah satu produk yang dapat meningkatkan nilai ekonomi dari buah pisang dan menjadi jajanan yang cocok dikonsumsi segala kalangan. Factor produksi banana roll tergolong cukup murah dan mudah didapat. Alasan memilih banana roll sebagai usaha karena melihat dari masyarakat yang mengonsumsi makanan siap saji sebagai pengganjal lapar sebelum waktu makan tiba. Sehingga membutuhkan jajanan yang mengandung banyak karbohidrat dari tepung terigu (kulit lumpia) dan gula untuk menabah energy dalam beraktivitas.

Diketahui manfaat banana roll yaitu kandungan potassium dan kalium dari pisang dapat melancarkan peredaran darah serta mengatur peredaran darah, kandungan karbohidrat yang diperoleh dari kulit lumpia dan gula dapat menambah energy energy, serta coklat yang dapat menaikkan mood karena mengonsumsi coklat dapat menurunkan hormone kortisol yang dihasilkan tubuh saat stress dan merangsang otak untuk melepaskan hormone endorphin(hormone yang membuat orang merasa senang) juga serotonin (hormone yang berperan penting dalam memperbaiki suasana hati) yang dapat membuat anda merasa bahagia.

Akan tetapi, mengonsumsi makanan cepat saji yang manis dan mengandung minyak secara berlebihan juga tidak baik untuk tubuh karena dapat menyebabkan dampak buruk bagi tubuh seperti diabetes, kolesterol, obesitas dan lain-lain. Jadi dalam mengonsumsi makanan cepat saji 
secukupnya saja jangan berlebihan agar dapat terhindar dari dampak buruk tersebut.

\section{B. Persiapan dan Proses Pembuatan Banana Roll}

Adapun dalam proses persiapan dan pembuatan banana roll ini, yang pertama kami lakukan yaitu mencari tau apa saja alat dan bahan yang digunakan dalam bisnis Banana Roll.

Adapun alat dan bahan yang digunakan dalam membuat Banana Roll yaitu :

\begin{tabular}{|l|l|}
\hline \multicolumn{1}{|c|}{ Bahan } & \multicolumn{1}{c|}{ Alat } \\
\hline 1. pisang & 1. kompor \\
2. kulit Lumpia & 2. wajan dan panci kecil \\
3. gula & 3. spatula \\
4. coklat batang & 4. sendok \\
5. susu kental Manis & 5. piring \\
6. air & 6. tirisan minyak \\
7. minyak & 7. dll \\
8. oreo & \\
\hline
\end{tabular}

\section{Cara Membuat :}

1. Potong potong memanjang pisang

2. Siapkan kulit lumpia, letakkan pisang dan gula diatas kulit lumpia.

3. Lipat kedalam sisi kanan dan kiri kulit lumpia kemudian gulung dan rekatkan ujungnya menggunakan air

4. Lakukan hingga bahan habis

5. Setelah itu goreng hingga matang atau berwarna coklat keemasan, lakukan hingga semua gulungan habis

6. Langkah selanjutnya yaitu membuat topping dengan cara memotong coklat batang kemudian masukkan ke piring stainless 
7. Campurkan susu yang sudah dicairkan kedalam coklat yang sudah dipotong

8. Panaskan air pada panci kecil lalu letakkan piring stainless yang berisi coklat dan susu diatas panci.

9. Panaskan coklat lalu aduk dengan sendok hingga mencair. Teknik pencairan coklat ini disebut dengan teknik double boiler.

10. Setelah mencair, tuangkan lelehan coklat ke atas banana roll yang telah digoreng tadi kemudian diberi remahan oreo (optional).

\section{Aspek Rencana Usaha}

1. Aspek Pemasaran

Dalam usaha Banana Roll ini, pemasarannya dilakukan disekitar wilayah Samata-Gowa, dekat dengan tempat pembuatan/produksi serta lingkungan kampus. Segmen pasar yang dituju adalah semua kalangan usia.

2. Aspek Ekonomi Sosial

Produk makanan banana roll ini dapat dikonsumsi oleh segala tingkat ekonomi. Terutama bagi mahasiswa karena harganya yang murah.

\section{Analisis SWOT}

Kami melakukan analisis dilingkungan sekitar melalui analisis SWOT untuk mengukur seberapa besar kemampuan kami dalam bersaing dipasaran.

a. Strength (kekuatan) :melihat apa yang menjadi kekuatan produk sehingga dapat mengukur kemampuan dan potensi produk yang dijual:

- Harga yang murah sehingga dapat dibeli kalangan menengah ke atas maupun menengah kebawah.

- Bahan yang digunakan halal

b. Weakness (Kelemahan)

- Produknya mudah ditiru

- Tidak dapat bertahan lama 
- Rasanya yang manis memungkinkan beberapa orang yang kurang suka manis tidak tertarik

c. Opportunity (Peluang)

- Fasilitas yang cukup memadai

- Bahan yang mudah didapatkan

- Proses penjualan yang strategis

- Disukai kalangan anak-anak hingga dewasa

d. Threath (Ancaman)

Produk yang mudah ditiru memungkinkan banyaknya pesaing yang akan bermunculan.

\section{Strategi Pemasaran Produk}

1. Produk

Produk yang dijual harus memiliki nilai ekonomis tapi tetap berkualitas. Pengemasannya juga harus bersih dan menarik perhatian

2. Price (harga)

Harga yang kami tetapkan berdasarkan kualitas produk serta menyeimbangkan dengan harga bahan. Adapun harga yang kami tetapkan yaitu:

- Banana Roll topping coklat oreo

Rp. 5.000/porsi

- Banana Roll topping coklat susu

Rp. 5.000/porsi

3. Promotion (promosi)

Promosi merupakan upaya untuk menawarkan produk/jasa kepada masyarakat dengan tujuan menarik calon konsumen untuk membeli. Adapun dalam bisnis ini, promosi yang dilakukan dengan cara online, yaitu menyebar flyer ke social media seperti whatsapp, instagram, facebook dll. Guna menarik calon konsumen. 
E. Rencana Anggaran Biaya (RAB)

1. RAB

- Rencana Anggaran Biaya Peralatan (Fix Cost)

\begin{tabular}{|l|l|c|c|c|c|}
\hline No & \multicolumn{1}{|c|}{ Nama } & Satuan & Jumlah & $\begin{array}{c}\text { Harga Satuan } \\
\text { (Rp) }\end{array}$ & $\begin{array}{c}\text { Jumlah Harga } \\
\text { (Rp) }\end{array}$ \\
\hline 1. & plastik Mika & Pcs & 100 & RP. 100 & Rp. 10.000 \\
\hline 2. & Isi Staples & Pcs & 2 & RP. 100 & Rp. 2000 \\
\hline \multicolumn{6}{|c|}{ Total } \\
\hline
\end{tabular}

- Rencana Anggaran Biaya Bahan (Variabel Cost)

\begin{tabular}{|c|l|c|c|l|l|}
\hline No & Nama & Satuan & Jumlah & $\begin{array}{l}\text { Harga Satuan } \\
\text { (Rp) }\end{array}$ & $\begin{array}{l}\text { Jumlah Harga } \\
\text { (Rp) }\end{array}$ \\
\hline 1 & Pisang & sisir & 1 & Rp.7000 & Rp.7000 \\
2 & Kulit Lumpia & Bks & 1 & Rp. 15.000 & Rp. 15.000 \\
3 & Gula Pasir & Ltr & 1 & Rp. 6000 & Rp. 6000 \\
4 & Coklat batang & Kg & 1 & Rp. 25.000 & Rp. 25.000 \\
& Susu kental & & & & Rp. 11.000 \\
5 & Manis & kaleng & 1 & Rp. 11.000 & - \\
6 & Air & - & - & - & Rp. 14.000 \\
7 & Minyak & Ltr & 1 & Rp. 14.000 & Rp. 78.000 \\
\hline \multicolumn{7}{|c|}{ Total } \\
\hline
\end{tabular}

\section{Perhitungan Biaya}

Total biaya yang dikeluarkan untuk memulai bisnis usaha Banana Roll

Total biaya Anggaran :

1. Biaya peralatan $=$ Rp. 12.000

2. Biaya Bahan $=$ Rp. $78.000+$

\begin{tabular}{ll} 
Total & $=$ Rp. 90.000 \\
Modal Awal & $=$ Rp. $160.000-$ \\
\hline Total & $=$ Rp. 70.000
\end{tabular}




\section{Perhitungan Penghasilan}

Pembuatan Banana Roll ini dalam hitungan 1 bulan, dimana dijalankan pada saat mempunyai waktu luang, menghasilkan penjualan:

- Minggu pertama = Rp. 40.000

- Minggu kedua = Rp. 50.000

- Minggu ketiga = Rp. 35.000

- Minggu keempat $=$ Rp. $30.000+$

Total

$=$ Rp. 155.000

\section{Perhitungan Laba/Rugi}

- Penghasilan Usaha = Rp.155.000

- Biaya yang dikeluarkan = Rp.90.000

- Laba/rugi = penghasilan-pengeluaran

$=$ Rp.155.000-Rp. 90.000

$=$ Rp. 65.000 (dalam 1 bulan) 
HASIL DOKUMENTASI
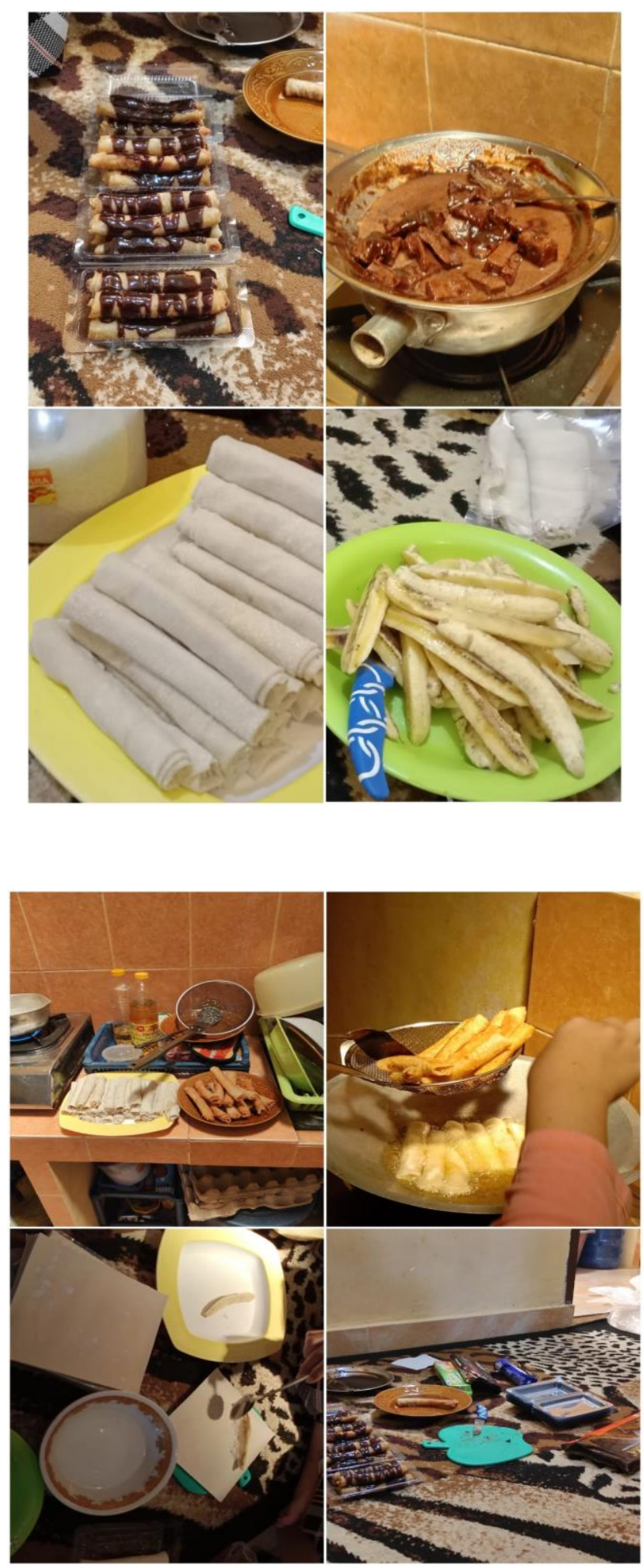


\section{BAB III}

\section{PENUTUP}

\section{A. Kesimpulan}

Banana roll merupakan pisang yang dibalut dengan kulit lumpia dengan toppig coklat leleh diatasnya. Produk ini merupakan salah satu produk yang dapat meningkatkan nilai ekonomi dari buah pisang dan menjadi jajanan yang cocok dikonsumsi segala kalangan. Factor produksi banana roll tergolong cukup murah dan mudah didapat. Sehingga membutuhkan jajanan yang mengandung banyak karbohidrat dari tepung terigu dan gula untuk menabah energy dalam beraktivitas.

Diketahui manfaat banana roll yaitu kandungan potassium dan kalium dari pisang dapat melancarkan peredaran darah serta mengatur peredaran darah, kandungan karbohidrat yang diperoleh dari kulit lumpia dan gula dapat menambah energy energy, serta coklat yang dapat menaikkan mood karena mengonsumsi coklat dapat menurunkan hormone kortisol yang dihasilkan tubuh saat stress dan merangsang otak untuk melepaskan hormone endorphin juga serotonin yang dapat membuat anda merasa bahagia.

\section{B.Saran}

Dengan mengucapkan syukur Alhamdulillah pada allah SWT penulis dapat menyelesaikan makalah ini dengan baik dan tentunya masih jauh dari harapan .oleh karena itu penulis masih perlu saran ataupun kritik yang membangun serta bimbngan ,terutama dari dosen.semoga makalah ini bermanfaat bagi pembaca dan penulis . 


\section{DAFTAR PUSTAKA}

https://cookpad.com/id/cari/crispy\%20banana\%20roll

https://cookpad.com/id/resep/6386558-banana-roll-crispy

http://bblumpiapisang.blogspot.com/2017/06/bussines-plan-banana-butt.html?m=1

https://ideresep.vercel.app/887-bagaimana-membuat-banana-roll-crispy-anti-gagal/ 